\title{
Childhood and Poverty in Leon in the Modern Period: Institutional Responses
}

\author{
Alfredo Martín García
}

\section{The View of Children in the Spain of the Sixteenth to Eighteenth Centuries}

I $\mathrm{n}$ the sixteenth century the first steps began to be taken in Europe to bring into practice the theoretical models for protecting children that had started to evolve in the later Middle Ages. In the Spain of that time certain thinkers, such as Luis Vives or Miguel de Giginta ${ }^{1}$, began to put forward solutions, especially with regard to abandoned children. In general, it was not a case of specific works on the question, but rather of discussion of the topic of childhood in a tangential way, integrated into their analyses of the overall phenomenon of poverty. Vives, in his famous Socorro de los pobres [Aiding the Poor], advocated the establishment in the chief cities of the realm of centres to aid abandoned children, where they would receive attention of all sorts ${ }^{2}$. The idea of all these writers was closely linked to the need to keep children from begging, because of all the terrible drawbacks that this would bring, starting with the exploitation of minors and going on to their highly likely slide into delinquency. In brief, these policies brought together the traditional spirit of Christian charity from the Middle Ages ${ }^{3}$ and a growing fear of the poor as subversive. Alongside these points of view a major part was also played by more financial criteria; these sought to make individuals useful through intellectual,

1 Vives, Juan Luis, (2006), Tratado del socorro de pobres [Treatise on Aiding the Poor], (Unpublished sixteenth-century translation by Bernardo Pérez de Chinchón) Alicante: Generalitat de Valencia [Regional Government of Valencia] and Diputació de Alicante [Alicante Provincial Council] (First edition published in Latin in Bruges, 1525); Giginta, Manuel de (2000), Tratado de remedio de pobres, Barcelona: Ariel (First edition, Coimbra 1579).

2 Vives, Juan Luis, Tratado del socorro..., (2006), p. 189.

3 In accordance with this line of argument, poverty should be considered not so much a social curse as a blessing from God, since thanks to it the rich could gain salvation through giving alms. Cavillac, M. "Introducción" in Pérez de Herrera, Cristóbal, Amparo de pobres, Madrid: Espasa-Calpe, pp. LXXXV-LXXI (1975). 
religious and vocational training ${ }^{4}$. Both Vives and the majority of the thinkers of the period held that there should be direct participation by the State in the work of gathering and supporting the poor. However, the results achieved were of no great significance, even though it seems clear that their thinking influenced the founding or development of a range of charitable institutions, generally supported by the Church, whether by members of the clergy or of religious associations.

As time passed, the image of children acquired sharper edges and gained a defined legal status. This change in the view of the world of childhood can be clearly noted already in the seventeenth century, under the influence of the Counter-Reformation. A more Christian set of customs and the discovery of children's souls gave infants dignity, as may be seen in treatises and legislation from the period ${ }^{5}$. This tendency was accentuated during the eighteenth century. At that time, the Enlightenment concepts of utilitarianism, philanthropy, stimulating population growth, and rationalism gave a new dimension to interest in childhood as a whole, and abandoned children in particular. As had already happened in the sixteenth century, writers of the Enlightenment once more stressed the need for greater involvement by the State in the task of aiding the marginalized. Their influence had practical consequences for legislation, but not in the form of direct management by the Crown of any establishments opened for such people, the Church retaining its primacy in these activities ${ }^{6}$.

The objective of this paper is to analyse the impact of all these changing views on assistance to children in a specific instance (the City of Leon) during a given period (Sixteenth to Eighteenth Centuries) ${ }^{7}$. A study of the case of Leon is of great interest for several reasons. The fact that the general characteristics of aid to children in a Spanish provincial city during the modern era are known helps judge accurately the importance of Crown legislation in this field. Similarly, an investigation of the main institutions devoted to this work during the centuries in question is helpful in understanding what the principal objectives of the actions of these foundations were and how they changed over the years. Among the modifications in the priorities set by centres in Leon for assistance, from the eighteenth century onwards it is striking how much stress was laid on education as a necessary bridge to the

4 Maravall, José Antonio "De la misericordia a la justicia social en la economía del trabajo: la obra de Fray Juan de Robles", in Moneda y Crédito. Revista de Economía, 148, (1979), pp. 57-88, pp. 59-60.

5 Ariés, Philippe, El niño y la vida familiar en el Antiguo Régimen, Madrid: Taurus, (1987), p. 69.

6 Cava López, Gema, Infancia y sociedad en la Alta Extremadura durante el Antiguo Régimen, Cáceres: Institución Cultural "El Brocense”, (2000), pp. 42-43.

7 Abbreviations used hereafter: A.H.P.L. = Archivo Histórico Provincial de León [Leon Provincial Historical Archives]; A.CH.V. = Archivo de la Real Chancillería de Valladolid [Valladolid Royal Chancellery Archives]; A.M.L. = Archivo Municipal de León [Leon Municipal Archives]. 
integration of children into society. For this reason, particular attention will be paid to the question, consideration being given to its background and outcomes in the world of childhood in Leon.

\section{Various Responses to the Phenomenon of Children in Need in the City of Leon: The Poor Fund, the Hospice and the Doctrinal School}

The City of Leon, like so many other towns in the Europe of the time prior to constitutional monarchies, sought to meet the demand for aid for marginalized children through a range of institutions of various kinds. To meet the problem of foundlings and abandoned children, the Leonese set up two charitable bodies: the Poor Fund and the Hospice. In their origins, going back a long way in time, both were overwhelmingly religious in nature, in no way strange if it is kept in mind that it was precisely Christian charity that was the prime mover in the development of this sort of assistance ${ }^{8}$. While the Fund was a foundation dependent upon the Cathedral Chapter, the Hospice was born thanks to the desire for reform of Bishop Cayetano Cuadrillero. The status of the City of Leon as the See of a bishopric and capital of one of the kingdoms composing Spain led these institutions to extend their aid work not just to the City itself but also to its extensive Province. For its part, the third of the centres in existence in Leon at that time, the Colegio de niños de la doctrina cristiana [literally, Children's school of Christian doctrine], or Doctrinal School, was alone in not being directly managed by the Church, since control over it was exercised by the City Council. In any case, this centre, while devoted to the intellectual and vocational training of orphans, was also the fruit of the Christian concept of charity and the era's keenness on catechizing.

\section{The Poor Fund The "Arca de Misericordia"}

For much of the modern period, the work of aiding abandoned children in the City of Leon was the sole preserve of the Arca de Misericordia de Nuestra Señora la Blanca [literally, Chest of compassion of Our Lady the white virgin], or Poor Fund. Until it disappeared at the start of the nineteenth century, this charity was under the control of the Cathedral Chapter. Although the exact date of its foundation is not known, there are numerous references to its activity from the last few decades of the fifteenth century onwards. The Chapter's aid work continued over later years,

8 Fonte (DA) T.A., No limiar da honra e da pobreza. A infancia desvalida e abandonada no Alto Minho (1698-1924) (Vila Praia de Âncora 2005), p. 114. 
meeting the costs incurred for wet-nurses both from its own resources and with the alms of the faithful. As the sixteenth century wore on, the initially very sketchy organizational arrangements for the centre were gradually refined, and it gained its own financial resources. In parallel with this development, absolute subordination to the Chapter gradually gave way to a certain degree of autonomy, thanks to the diversification of sources of income. The charity acquired privileges from Rome, from the Crown and even from the Leonese church itself, as well as receiving donations from private individuals ${ }^{9}$. However, without any doubt the change of greatest importance with reference to achieving full financial self-sufficiency occurred in 1771, when it was awarded the income from a tax on the sale of wine, called the arbitrio del vino, or wine levy. This amounted to two maravedis per azumbre $^{10}$ [very roughly equivalent in English terms of the period to half a farthing a pint] on wine sold in the city and certain parts of its surrounding Province.

It is no coincidence that receipt of this major favour occurred chronologically at the high point of Bourbon reformism. At that time, the Christian vision of aid to the needy was joined by the utilitarian views of the Crown, which saw in the loss of children an intolerable drain that put a brake on the growth of the population and hence on the economic development of the country. Besides, approval of this grant was also a response to complaints by the Chapter that with the limited budget the charity had it could not cope with the flood of abandoned children, coming not just from the Bishopric of Leon, but also from the Astorga diocese, including the towns of Villafranca del Bierzo and Ponferrada, as well as from the deanery of San Millán in the Bishopric of Oviedo and from those parts of the mountains falling within the Kingdom of Leon, right up to the boundary with the Principality of Asturias ${ }^{11}$.

To solve these difficulties, the Chapter requested from the Crown the assignment of a sufficient and stable source of income which would not merely meet current costs, but might also allow the development of a more complete provision of assistance to children. Specifically, it might allow them access to educational and vocational training such that in the future they could enter the labour market with some hopes of success. The new tax, once consolidated, amounted to more than $50 \%$ of the institution's yearly income. Besides bringing financial stability to the body, the levy led to a major change in the process of gathering up foundlings from other parts of the Province. From 1772 onwards, those towns and villages that paid this tax were exempted from their obligation to

9 See Villacorta Rodríguez, T., El Cabildo de la Catedral de León. Estudio Históricojurídico, siglos XII-XIX (Leon 1974).

10 The azumbre was a measure for liquids approximately equivalent to two litres or four pints; the maravedi was at this time a small copper coin.

11 A.M.L., Box 729. 
pay any of the costs for the care of foundlings from their area, since all such expenses were taken on by the charitable body.

\section{The Doctrinal School}

Another of the institutions intended to provide assistance linked to children that existed in the City of Leon was the Doctrinal School. Its creation and development over the sixteenth and seventeenth centuries mirror perfectly the parameters governing charity at that time, when it was seen as preferable to attend to and educate orphans, the children of "honourable families", rather than foundlings, often the "fruit of $\sin ^{12}$. The origins of this Leonese charity lie in the rise of institutions of this sort throughout the Kingdom of Castile during the sixteenth century. Effectively, while predecessor foundations of a similar nature are known from the late Middle Ages, it is usually the year 1540 that is taken as the start of the process. It was from that year that the Crown began to become involved in developing such works, exhorting local authorities to try to prevent participation by children in begging, helping them to learn a trade and covering their most basic needs. These measures, sanctioned by Charles V, were nothing more than an adaptation to a Spanish context of the guidelines that the Emperor had applied some years before in Flanders. The main way in which Castilian cities expressed their response to this request by the Crown was the creation of doctrinal schools. This was because they were affected by the development of a strong catechizing movement, headed by Saint John of Avila and his disciples, who aspired to an ambitious plan for the religious and educational reform of the lower classes ${ }^{13}$.

The process appears to have its true beginning in 1542 when Valladolid opened its school ${ }^{14}$. One year later, steps were initiated to create an establishment of the same characteristics in Madrid, and then the formula was extended rapidly throughout the land (in Burgos, Avila, Seville, Cadiz, Toledo, Jerez de la Frontera and elsewhere). In the 1550 s the project was set on a sure footing thanks to support from Philip II in the shape of a Royal Warrant (1553), inspired by the memorandum presented a year earlier by Gregorio de Pesquera and Juan de Lequeitio to the Council of Castile. The objective of this royal order was to consolidate those foundations already in existence and promote new creations,

12 Caro López, C., La línea en la sombra. Estudios sobre la asistencia y la represión de los marginados en Murcia durante el siglo XVIII (Cartagena 1992), p. 38.

13 Santolaria Sierra, F., "Los colegios de doctrinos o de niños de la doctrina cristiana. Nuevos datos y fuentes documentales para su estudio" in Hispania, Vol. LVI-1, 192 (1996), pp. 267-290, p. 269.

14 See Fernández Martin, L., Asistencia social en Valladolid. Siglos XVI-XVIII (Valladolid 1999). 
involving municipal authorities in maintaining them ${ }^{15}$. It is very likely that the Doctrinal School in Leon owed its origin to these measures taken by the Crown. This is, for the moment, a hypothesis lacking any documentary proof, since the source that ought to be able to provide this information (the Minute Books of the City Council) is not extant for this period. It is, nonetheless, certain that the school was already in operation in the 1560s, since in 1571 the Leon City Council, the patron of the foundation, paid the centre the arrears of emoluments that it should have handed over in 1567,1568 and $1569^{16}$.

The school was set up in the Sanctuary of Our Lady of the Remedies, situated outside the city wall. To ensure it ran smoothly, the Council annually elected an individual to the post of Administrator of the Doctrine Children. Some of these administrators took a lively interest in the foundation, even contributing from their own funds to supporting the children. When the Council was faced by the arrival of a mass of poor in the city in July 1699, it handed the Remedies Sanctuary over to the Bishop so that a provisional hostel could be set up there. Don Gaspar de Teves, the children's administrator, took them off to his own home while this emergency was being resolved ${ }^{17}$.

Despite the commitment of the municipal authorities to the good functioning of the institution, it is certain that the school had right from the start only a very limited income. In the final third of the sixteenth century, the municipality contributed to it from its own funds just 6,000 maravedis a year [at that time equating very roughly to some 120 to 150 English shillings of the same period]. This is a very modest sum if compared, for instance, with the 50,000 maravedis that at around this time the Municipality of Toledo was giving to its school ${ }^{18}$. In addition to this fixed contribution, the Council came to the aid of the centre with money at moments of extreme need, especially when it became urgent to undertake repairs to the installations or to renew the pupils' clothing. Thus, at the beginning of September 1642 the Council enjoined Alderman Don Álvaro de Quirós Miranda to ensure the Doctrinal School children were properly clothed, and in October 1705 , the municipality spent 1,800 reals [at this time the real de plata was a silver coin worth somewhat less than an English shilling, so that the full amount equates to fifty or sixty guineas of the period] on improvement works at the Sanctuary ${ }^{19}$. At other times, the City Council directed some of the money from fines imposed on

15 Santolaria Sierra, F., "Los colegios de doctrinos o de niños...", (1996), p. 284.

16 A.M.L., Box 37, Libro de actas [Minute Book] No. 9, folio 17.

17 A.M.L., Box 63, Libro de actas No. 54, folio 340 verso.

18 The amounts spent by Leon are more similar to those expended by the city of Logroño. Mora del Pozo, G., El colegio de doctrinos y la enseñanza de primeras letras en Toledo. Siglos XVI a XIX (Toledo 1984), p. 75; Lope Toledo, J .M., "Logroño en el siglo XVI. Los niños de la doctrina cristiana", pp. 419-432 in Berceo, 73 (1964), p. 420.

19 A.M.L., Boxes 50 and 65. 
its staff to the benefit of the foundation or transferred to it the residues of income obtained from other sources. There are several examples of this to be found during the 1740s, when the Council gave the school the revenue from sales of beef from the animals killed in bullfights ${ }^{20}$. As for the first of these kinds of extraordinary income, there is evidence from January 1714, when the Councillors decided to deduct 20 reals from their Chaplain's salary for failing to attending some of the masses to which he was required to go, and to apply this money to the school ${ }^{21}$.

Besides the financial contributions from the City Council, there were other sources of income: alms collected by the children themselves, donations by individuals and bequests in wills given so that the children would attend the funeral. Those bequeathing money in this way so as to have children present at their burial were trying to benefit from the children's reflected innocence at the tragic moment when they left the world, given their uncertainty about salvation ${ }^{22}$. This funerary practice was primarily linked to the wealthiest sectors of seventeenthcentury Leonese society. Two examples would be the cases of Doña Juana Bañuelos and Doña Manuela de Aldama. Both stipulated in their wills, dating from 1675 and 1685 respectively, that the Doctrinal School children should be called to escort the coffin of the deceased to the graveside, wearing veils and praying for the soul of the departed $^{23}$. The decline of the school in the eighteenth century led to the disappearance of the practice at that time.

This range of revenues, unfortunately, never sufficed to cover all the expenditure the foundation required, leading to a financial shakiness that continued from its birth to its disappearance. As early as 1601, the children were obliged to leave the building because of the poor state of the facilities ${ }^{24}$. At that time there were six little ones living in the school and receiving free primary education from the City's schoolmaster. One hundred years later, the school was still suffering from the same financial penury, as its administrator, Don Gaspar de Teves, pointed out in 1700. The cause of this instability lay, to quote the words of an alderman from 1642, in the fact that it had no income from endowments and that charitable donations were insufficient to cover its costs ${ }^{25}$.

20 In September 1645 this amounted to 85 reals; in February 1650, to 100 reals. A.M.L., Boxes 51 and 52.

21 A.M.L.,

22 These sources of finance were very similar to those seen in the schools in other cities, such as Toledo or Palencia. González Gallego, I., "El proyecto didáctico de una institución educativa entre los siglos XVI y XIX: el Colegio de niños de la doctrina cristiana de Palencia (1544-1861)", pp. 475-497, in Actas del I Congreso de Historia de Palencia, Vol. III (Edad Moderna y Edad Comtemporánea), Palencia 1987, p. 477.

23 A.H.P.L., Protocolos notariales, Boxes 333 and 459.

24 A.M.L., Libros de actas, Box 44.

25 A.M.L., Box 51. 
This precarious state, together with the development of the Poor Fund, brought about the decline of the school, clearly visible in the mid-eighteenth century from the information provided as General Responses drawn up for the National Survey of the Marquis de la Ensenada in 1752. At that point, the old school no longer lodged any children and was evidently in a decrepit state ${ }^{26}$. A few decades later, specifically in 1773, Alderman Don Antonio Escobar presented an ambitious project to rehabilitate the school and remedy this unfortunate situation. Escobar's plans, supported by the Leon City Council, were largely an outcome of the disputes that had arisen between the Council and the Cathedral Chapter over the granting by the Crown of the levy for the Poor Fund. The municipal authorities considered that the sums collected for the benefit of that charitable institution were much larger than its real needs. Consequently, they pressed for a suitable redistribution of the money in question, with some part of it to be spent on other necessities also relating to aid for the poor of the city and its environs. One of the possibilities suggested by the Councillors was the re-establishment of the Hostel for the Needy of Our Lady of the Remedies. In this way, it would be possible to collect up, offer care to, and make useful a significant number of children who were in need, either because they had no parents or because these had abandoned them. In the Councillors' opinion, this foundation would not merely benefit residents of the city, but also the inhabitants of all the villages round it that were paying the levy at that time ${ }^{27}$. The project, however, did not prosper, the Doctrinal School disappearing definitively as new institutions, with a more modern conception of aid to the needy young, developed.

\section{Bishop Cuadrillero's Hospice}

It was in 1793 that the third aid centre in the city, the Hospice, first opened its doors. Its birth implied an undeniable advance in childhood protection policies in the City of Leon and its Province, both because of its ambitious objectives and because the building that housed the new institution had been purpose-built for its functions ${ }^{28}$. The idea of setting up an establishment of this nature had already been mooted in 1750 . However, the initiative came to nothing until years later, when a new Bishop, Don Cayetano Antonio Cuadrillero, came to take over the diocese in 1778. During his time as Bishop of Ciudad Rodrigo, this prelate had already set examples of reformist initiatives, founding a rather similar institution there, very

26 A.H.P.L., Catastro de Ensenada [Ensenada Survey], General Responses.

27 A.M.L., Box No. 76.

28 A plan of the building is to be found in the Archives of the Royal Chancellery of Valladolid. A.R.CH.V., Planos y Dibujos [Plans and Drawings], No. 182. 
much on the lines of the policies adopted by other Enlightened bishops ${ }^{29}$. Under his protection, the Crown resolved on 24 January 1786 to found a Hospice in the City of Leon. However, the Bishop's involvement in the creation of the new centre went beyond merely using his influences at Court, as he spent an appreciable amount on the affair: something of the order of three million reals [around one hundred thousand English guineas of the period].

Just as the Poor Fund had gradually built up a structured income that allowed it to enjoy relative autonomy, the Hospice followed the same route. It is true that in its first few years of operations funding came almost exclusively from the pocket of Bishop Cuadrillero, but as time went by it moved onto a financial footing that was less weak. This strengthening of the institution received an efficacious contribution from the careful management of Don Rafael Daniel, Archdeacon of Valderas. This clergyman was named by the Crown to take charge of the establishment in April 1800, after the illustrious Bishop himself had died.

In the early nineteenth century the co-existence of this new centre and the Poor Fund was somewhat problematic, leading to not a few disagreements that took the shape of noisy confrontations between Bishop Cuadrillero and his Chapter. It is possible that Cuadrillero's awareness of the opposition of the Chapter to his work led him to take the precaution of requesting that after his death the Hospice should remain under the control of the Colecturia general de expolios y vacantes del reino [Spanish State Office for Interim Administration of Church Property] and not of his successor as bishop, as would have been expected. The Bishop's suspicions were rapidly confirmed, with opposition to the centre growing more forceful after its founder's death in 1800 . The new administrator complained a year later that a large part of the Cathedral Chapter disliked the Hospice so much that they had never gone inside it, not even out of curiosity to see the great building, something which struck passers-by. Despite these pressures, the Hospice came out victorious when it achieved a merger with the Poor Fund in 1802.

The financial consolidation of the Hospice, once it took over the Poor Fund, and continuing support from the Crown did not leave the Director idle. Another of his aims was to encourage manufacturing work in the centre. Specifically, in 1803 he sent a report to the Crown, in which he indicated his wish to make the Hospice into a flagship manufacturing centre that could compete even with goods imported from abroad. Prudent management by Archdeacon Daniel was crucial during the Peninsular War years (1808 to 1814), when, despite the gloomy general situation, he was able to keep the Hospice at more than acceptable levels of effectiveness. On 4 January 1809, five days after the French invaders occupied Leon, one part of the installations was converted into a temporary hospital for their Army. Fortunately,

29 See Sarrailh, J., La España Ilustrada de la segunda mitad del siglo XVIII (Madrid 1974), pp. 138-139. 
the drop in income arising from difficulties the Hospice had in collecting what was due to it was to some extent compensated for by the good relations Archdeacon Daniel maintained with the new political authorities. On a personal level, this good understanding with the French caused him no little trouble at a later date. In June 1812, Don Rafael had to leave the city hurriedly in view of the threats uttered against him by Spanish partisans who accused him of being an afrancesado [Francophile traitor]. His hasty departure was one of the main causes of the decline into which the centre fell thereafter.

While during the Peninsular War the Hospice had suffered a major drop in the income it could collect, the reforms undertaken during the "Liberal Triennium" of 1820 to 1823 were no better for it, also having a negative effect on the revenues of the charitable organization, as has been observed in the case of other similar centres $^{30}$. Despite these fluctuations, so little to the benefit of the foundation, the Hospice did maintain a certain level of activity during the 1820 s, under the administration of the priest Don José María Román. His departure in 1835, coupled with the sweeping political changes that brought about the definitive end of the Modern Period, left the Hospice plunged into a difficult financial crisis. This unsustainable situation continued even after the Provincial Council of Leon, under the terms of a Royal Order of 30 November 1838, took charge of the centre. The new managers, thanks to the granting of fresh sources of funding, succeeded in getting the establishment back onto its feet, restoring the training and manufacturing activities that had been dropped during the long period of decline ${ }^{31}$.

\section{The Eighteenth Century: The Development of Education as an Objective for Aid}

During the sixteenth and seventeenth centuries, as has already been pointed out, there were two Leonese institutions that carried out childhood aid work: the Poor Fund and the Doctrinal School. The objectives of those responsible for the Poor Fund were confined to offering very basic assistance to foundlings. They attempted to gain spiritual salvation for the infants, guaranteed by the sacrament of baptism, and saw to their feeding, wet-nurses being hired in for this purpose. If the babies managed to get through this crucial stage for their survival, the Fund tried to ensure their adoption, whereupon it considered its own obligations ended. These aims of such reduced scope were a response both to the particular view of childhood at the

30 This also happened in Salamanca. Torrubia Balagué., Marginación y pobreza. Expósitos en Salamanca (1794-1825), Salamanca 2004, p. 64

31 Madoz, P., Diccionario geográfico-estadístico-histórico de España y sus posesiones de Ultramar (Valladolid 1983), p. 176. 
time and to the limits imposed by the sparse income available to the institution. For its part, the Doctrinal School offered its attentions to a tiny group of orphans, rarely more than half a dozen, to judge by what little information is available. In this centre, unlike the Poor Fund's approach, an attempt was made to give a solid Christian upbringing, combined with basic intellectual knowledge, provided by the City's schoolmasters. Likewise, the School tried to direct its pupils onto the labour market, giving them access to the exercise of a trade under the aegis of the Municipality. The model of the Doctrinal School is of great interest, because it saw education as an essential element in aiding children, so as to ensure appropriate integration into society. Despite the good intentions of the project, it was curtailed by the financial penury that affected the charity from its very beginning and restricted its capacity for action.

This extremely limited range of assistance changed considerably during the eighteenth century. The ending of the activity of the Doctrinal School in that century was more than compensated for both by the birth of a new centre, the Hospice, and by the new range of assistance given by this and the old Poor Fund. Between the two institutions, a total of 14,774 children were helped during the period 1700 to 1830 . Most of them, 11,653 (78.9\%), continued to be foundlings. Nevertheless, other types of assistance were on the up and up: these involved fosterlings, hospice children and grant aid. The first were children entrusted to the institution by their parents, theoretically on a temporary basis, while they resolved the financial problems that were preventing them from raising their own offspring. This new group took up $10 \%$ of the total of aid given, involving 1,476 families. With the setting up of the Hospice in 1792 hospice children also make an appearance, that is, children who on entering the centre had already exceeded the maximum age stipulated for external placement, so that they were kept in the establishment with a view to giving them an education and vocational training. These, who in some sense replace the Doctrine School children who had disappeared during that century, represented $5.1 \%$ of total outlays. The remaining $6 \%$ was split between grant aid and assistance to the mothers who worked as wetnurses and in child care in the institutions. The first of these consisted of financial assistance, generally in the form of cash, which the Hospice offered, fundamentally, to those parents requesting this sort of help, on condition that they committed themselves to raising their child at home. They were, in some sense, a more elaborate and modern version of fosterling and foundling arrangements, becoming general in particular during the first third of the nineteenth century.

Until the mid-eighteenth century, the Poor Fund carried on acting in its traditional way, restricting itself to the role of a centre redistributing the children that came to it, without direct participation in their education. However, from then onwards the institution started to take a more active part in the training of the youngsters who survived past weaning. Initially it had to rely on external education, 
handing the child over to the City's public school or to some master craftsman ${ }^{32}$, which had the additional advantage of starting a process of social integration ${ }^{33}$. This second route was frequently used by aid centres of this kind in eighteenth-century Spain, in view of the obvious financial benefits to the institution and the efficiency shown by the system ${ }^{34}$.

The granting of the wine levy in 1772 brought notable changes to the policy followed by the Fund. From then on, as they had an appreciable financial surplus, the administrators were able to contemplate the possibility of setting up their own workshops within the institution, using paid staff. In any case, it was not just financial factors that influenced the new features taken on by the centre. The keenness on matters utilitarian and educational so typical of eighteenth-century reformism also contributed notably to encouragement of this new dimension, as did the new way of seeing children and a rather blind confidence in education as a cure for all evils ${ }^{35}$. The first attempt on these lines was the creation of a spinning workshop. Between 1774 and 1776, the Fund spent a considerable sum of money on acquiring the equipment and raw materials needed to set up this establishment. In order to ensure adequate training for the children, it even gave a contract lasting rather more than a year to a German lady instructor whose task was to teach them to spin fine thread. Little by little, the manufactory fell into shape with the hiring of the requisite staff to ensure it functioned properly: in 1777, among others, the workshops had a master craftsman in woollen manufacture, a master wool-carder and a woman expert in combing wool ${ }^{36}$. This initial foundation was just the first of several with similar aims, although external apprenticeships never disappeared, since the workshops could not absorb all the children housed in the centre. This

32 It was fairly common practice across Europe at this time. See Vidal Galache, F. and Vidal Galache, B., Bordes y bastardos. Una historia de la inclusa de Madrid (Madrid 1995), pp. 137 et seqq.; Fauve-Chamoux, A., "Changing Politics towards Abandoned Children at the end of the Ancien Régime and the Responsibility of a French Hospital Administration on Infant Mortality", in World History Congress (Session: The Role of Purposive Behavior in Mortality Reduction) (Oslo 2000) (www.h-net.org/-demog/mortpap/fauve changl.doc), p. 10.

33 The sending of foundlings to public primary schools was also common in Saint James of Compostella or Valladolid. On occasions there was resistance from the schoolmasters, relating primarily to financial questions, since the centres did not pay any emoluments to the teachers. García Guerra, D., El Hospital Real de Santiago (1499-1804) (Corunna 1983), p. 355; Bartolomé Martínez, B., "La crianza y educación de los expósitos en España entre la Ilustración y el Romanticismo (1790-1835)", Historia de la Educación, 10 (1991), pp. 33-62, pp. 58-59.

34 Rodríguez González, A., "La utilidad del abandono: la expósitas del hospital de Santa Cruz y el servicio doméstico en Toledo en la segunda mitad del siglo XVIII", in Irigoyen López, A. and Pérez Ortiz, A. L. eds., Familia, transmisión y perpetuación (siglos XVI-XIX) (Murcia 2002), pp. $75-89$, p. 77.

35 Negrín Fajardo, O., "El niño expósito en el Despotismo...”, pp. 53-54.

36 A.D.P.L. Libros de cuentas del Arca de Misericordia. [Poor Fund Account Books] Box 218. 
traditional route was used more often as the numbers of children in the institution rose and mortality rates fell.

The Hospice founded by Bishop Cuadrillero in the 1790s was the continuer of the work started by the Poor Fund. The new centre even went beyond its predecessor, offering a type of aid that was novel to the City of Leon. This was the provision of vocational training, and even some basic general education, to a group of children who were older than the usual foundlings and fosterlings and who had thitherto had no direct relation with the establishment: these were the hospice children. Although, strictly speaking, this term could have been used to describe the whole infant population dependent on the Hospice and Poor Fund, here it will be restricted to meaning this new group who were helped by their charitable action. This is not a mere whim, as the administrators of the centre themselves used such a division in their registers. So, taking into account their differing origins, this study differentiates between hospice children and foundlings who survived being wetnursed, even though eventually both groups merged into the same status, enjoying similar attention and services.

\section{Putting the Young People into Work}

In analysing the incorporation of the children from the centres in the City of Leon into society, no chronological divisions have been made, as cases of this sort are concentrated into the period starting in the mid-eighteenth century. Prior to this, almost all the youngsters who survived past weaning were handed over to be adopted. Hence, they fall outside the boundaries of this study, as their links with the institution were definitively broken, and so also any reference to their later journey through life. It is evident that this approach taken by the Poor Fund was not ideal, but it is equally clear that the adoption route was the only one possible for the protection of a minor who otherwise would be most likely to end up a beggar. For this reason, it is easy to share the view of Larquie, who states that it would be wrong to take excessive pity on them as "victims" when treated in this way $^{37}$.

It is an extremely complex matter to undertake a study of how the children were brought into society, because of the major confusions in the data provided by the sources. These are excessively prolix in respect of some irrelevant items of information, but often very sparse in data that would seem fundamental. Thus, a considerable percentage of entries are to be found in which it is known that the child started a course of instruction, but there is no reliable indication that this learning was successfully completed. This large grouping is brought together in the

37 See Larquie, C., "La crianza de los niños madrileños abandonados en el siglo XVIII", Anales del Instituto de Estudios Madrileños (1986), pp. 363-384. 
statistics provided here under the generic heading of "lost" (Graphs 1 and 2). The grouping includes those individuals whose register entry ends with laconic expressions on the lines of "went away", "left care", "became independent", "departed", or "nothing further known". In all these cases, it would be very complicated to try to tease out the shade of meaning lying behind such wordings, so that any attempt at further analysis would be highly problematic, not implying any real advance in the investigation.

Another aspect constituting an obstacle to analysis is the relative frequency, especially for girls, of entering and leaving the institution. This circumstance doubtless made it difficult for the administrators to keep track, particularly when the young person decided unilaterally to leave the protection provided by the charity. Moreover, among boys there are also a large number of entries in which there is a change in the kind of instruction being provided, which makes follow-up harder. A few examples of this might be useful. In 1821 a young hospice boy from the establishment was sent out to learn the trade of cauldron-maker, but on returning to the centre was despatched again to be apprentice to a weaver. On 21 May 1839 another lad was sent off to train as a chair-maker, but a while later he was redirected to being a house-servant. In the light of these major variations, the statistics drawn up have taken account only of the closing item in the entry, in other words the last reference included in it.

After these caveats, necessary for a correct understanding of the data presented, analysis can begin. In it, the appropriate differentiation by sexes has been observed, in the light of the differing roles that males and females were assigned by the society of the period. Likewise, although an overall view is also offered, it seemed preferable to maintain the already mentioned internal differentiation between hospice children and foundlings. In total 846 records were studied, 471 relating to boys and 375 to girls $^{38}$. Girls are numerically prevalent among the foundlings, while boys are commoner among the hospice children. For males, this result corresponds to the logic of the day, since boys were more often handed over to this service than were girls. With regard to foundlings, the slight female predominance may be an outcome of the greater tendency of males to break off their link with the charity at an early stage, a behaviour pattern much less frequent among females, in view of the control exercised over them by institutions.

To begin with an analysis of the boys, what has already been indicated about the high percentage of "lost" cases should immediately be stressed, since they come to $46.7 \%$ of the total (figure 1). This result it clearly affected by the figures relating to hospice children, where $64.2 \%$ of the entries have no information on final destiny,

38 Those entries relating to foundlings and hospice children who died as adults without having left the institution have been omitted. 
Figure 1. Final outcome for surviving boys from the Leon centres, 1700-1830.

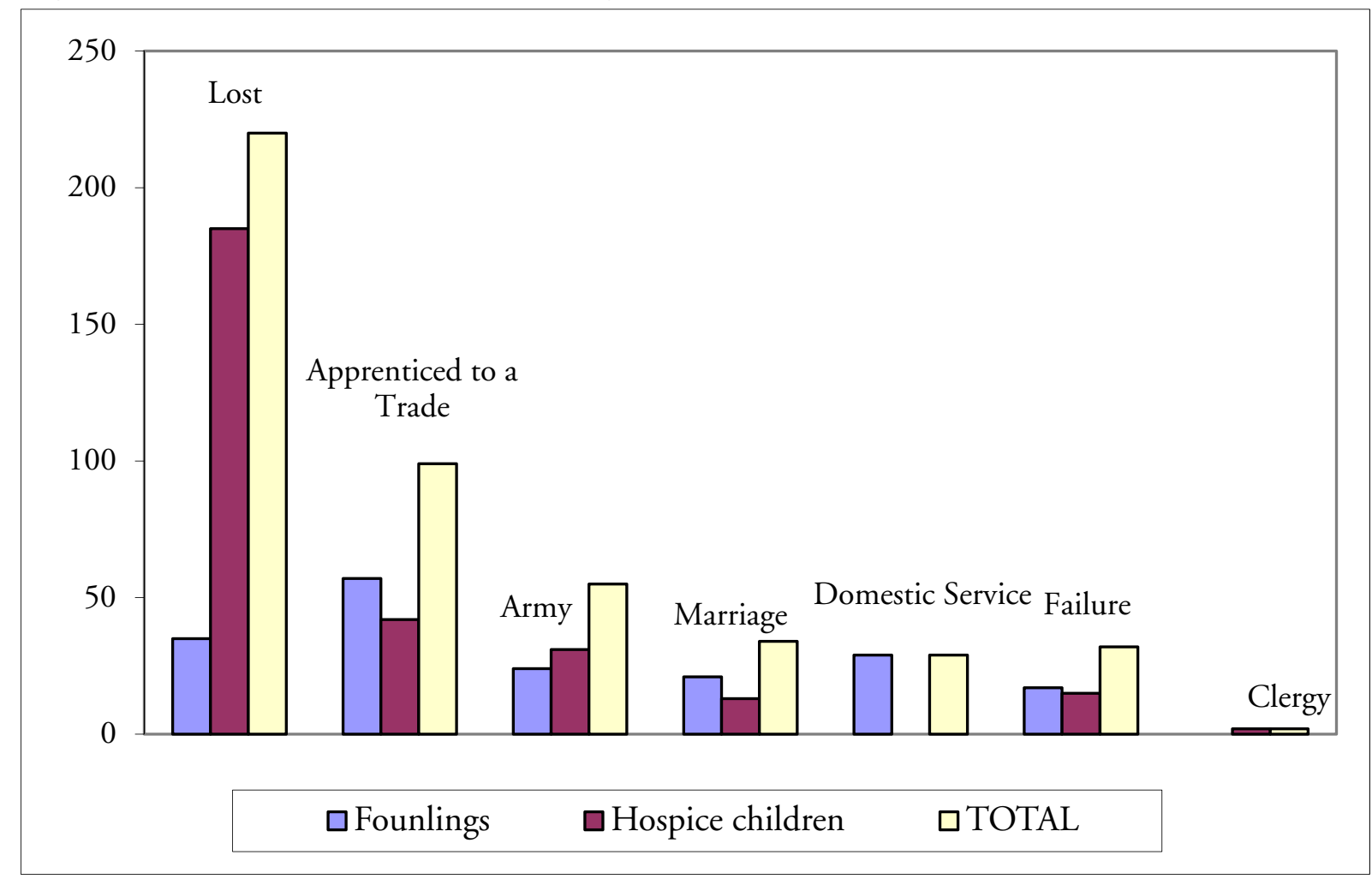

as against $19.1 \%$ among foundlings. The origin of these striking differences must be related to the different ages at entry of the members of the two groups. It should be taken into account that the average age at which hospice children came into the charity's care was 10.4 years, although a significant number were older than that on first entry. If it is remembered that the transition from childhood to adult status was much more abrupt in the society of those days, it is highly likely that this considerable number of "lost" hospice children is a consequence of their own course through life, which encouraged them to break their link with the institution when they no longer considered it useful for their interests. In fact, in many of these cases the entry ends with a succinct "nothing more known".

Alongside this considerable number of lads for whom the reason for their break with the centre is unknown, there are two training routes that were most frequent: an apprenticeship to learn a trade and joining the armed forces. For the first of these routes the percentage of foundlings was much higher than for hospice children (31.1\% versus $14.6 \%)$. However, the results for this group are strongly affected by the considerable number classed under the heading of "lost". For some of these it is known that before breaking their link with the institution they had undergone some training by a master craftsman, although it is not certain whether this was completed or broken off unilaterally before completion. If these "lost" or "missing" cases are excluded, the percentages for foundlings and hospice children are very similar. In both groups, being apprenticed to a trade was the chief route (38.5\% of the first group, $40 \%$ of the second). Within the range of trades, the 
textile sector is predominant: most of the boys were entrusted to a tailor, a weaver, or a haberdasher. Less frequent were the trades of carpenter, blacksmith, locksmith, confectioner or dyer, among others. As well as apprenticeship to craftsmen in the city, the documents also reflect the presence of a very small number of boys who succeeded in training for professions that were more specialized, and thus of greater social prestige: silversmiths, clergy or surgeons.

This sort of instruction for boys did not first arise in the eighteenth century, although it is true that that was the period when it became general. The most immediate predecessor to the practice, developed particularly by the Poor Fund, is to be found in the Doctrinal School. This institution, at least during the seventeenth century, acted in a similar way. Formal documents for the agreement always followed the model recorded in the Municipal Minutes for 21 May 1699. On that day the City Council of Leon promised to pay Domingo de Valdés, weaver, 150 reals to teach his trade to a boy from the school. Payment was to be made in two instalments, one at the start of the apprenticeship, the other at the end $^{39}$.

In the case of those hospice children whose parentage was known, the period of training implied no outlay at all by their family. As a counterpart, any profit from the children's work was assigned to the institution, completely at first and partially later, in that the charity might assign them some small gratuity as a stimulus. In March 1822, when a lad was sent to train as a haberdasher for two years, it was indicated that for that time he would have no right to request any recompense for his work, even though others in the same establishment were paid, but that he would be entitled to be lodged, fed and clothed exactly like any member of the household ${ }^{40}$. Some of these youngsters who completed their professional training ended up by working as master craftsmen in the institution that had arranged their apprenticeships. This was the case for the master weaver and master haberdasher that the Poor Fund was employing in $1801^{41}$. Others managed to find work away from Leon. This happened to a foundling supported by the Poor Fund, Antonio by name, who in January 1803 had obtained a certificate of examination as blacksmith and locksmith, for which success the institution paid him a gratuity of 66 reals. $\mathrm{He}$ stated that he had been speaking with the Council of Barcial del Barco, in the Benavente district about working as a blacksmith in that village under a contract that he expected to be signing with them in the following March. There were others: another foundling, Tomás Pareja, had left Leon at the age of 17 to continue an apprenticeship as guitar-maker with the master craftsman Don José Nieto, living in Montserrat Street in Madrid. The institution awarded him 40 reals towards the

39 A.M.L., Box 63. Hospice]

40 A.H.P.L. Libros registro de entradas del Hospicio de León. [Entry Registers for the Leon

41 A.H.P.L., Sanidady Beneficencia [Health and Welfare], Box 339. 
costs of the journey. Naturally, there was control by the institutions over the work carried out by these master craftsmen taking on apprentices, to avoid possible fraud. In April 1837 a foundling called Toribio was ordered back by the Leon Hospice from the house of the cobbler Miguel Sánchez, nicknamed "pot-head", because the latter had not taught the boy the trade in question, but had used him to look after his pigs and to serve his paying guests ${ }^{42}$.

The second option was to serve the King in the Army. This route took a larger number of hospice children than foundlings, perhaps because episodes of warfare were more frequent in the first third of the nineteenth century. In any case, whether in the Peninsular War, in the invasion by the "hundred thousand sons of Saint Louis" sent by the French King to enable King Ferdinand to overturn his own liberal government, or in the Carlist Wars of succession, this did not imply obligatory mobilization for the lads, since on most occasions it was recorded that the decision to join up was voluntary. This was the case of a foundling called Dionisio who, at 17 years of age, and with a background of being rather unruly, joined the Twelfth Infantry Regiment on 28 July 1841 as a musician. After six years of service, he returned to the Hospice, but went back into the army a year later, as a substitute for Florencio Núñez, who had been selected as one of the conscripts for the town of Sahagún for 1848, a total of 5,000 reals being paid by Núnez for this substitution relieving him of the need to serve. Indeed, such a step of acting as a replacement for somebody who had been chosen as a conscript, with money being paid for this service, is quite frequent among the foundlings. The charity continued to exercise a monitoring role over the young man concerned until he was discharged from service to the Crown.

After these two occupational choices, marriage was the third most frequent way of becoming independent from the Hospice, involving 7.2\% of the overall figures, $13.5 \%$ if the "missing" are left out of consideration. Evidently, the fact that the celebration of this ceremony brings the record to a close in no sense implies that it was the true cause of the ending of the link. It is logical to think that when a young fellow took this decision he would have the security of a job behind him and that this simply is not noted in the documents. The fourth most common outlet was domestic service, amounting to $6.2 \%$ of the total, $11.6 \%$ if inconclusive entries are omitted. However, this occupation appears only in the case of foundlings, perhaps because there was not an adequate infrastructure to absorb all those looking for an education. Besides, as a feature related to these deficiencies, it is possible that the fact that hospice children entered the charity's care expressly with the aim of their obtaining suitable training meant that they got priority over the foundlings in assignments to a destination. These young servants were usually entrusted to a master without being given any pay at all while they were being trained, but might

42 A.H.P.L. Libros registro de entradas del Hospicio de León. 
receive emoluments thereafter. In April 1843 Don Juan Antonio Prieto, resident at Herrín de Campos, had entrusted to him a foundling called Crisanto, on condition that he merely gave him board, lodging and clothing for the moment, but that when the boy reached the age of 17 years he would also have to pay him the wages he merited in accordance with the practice of the area ${ }^{43}$.

In a few other instances, merely anecdotal in terms of their percentage impact, the ending of the link with the centre was related to a very late recognition of the parentage of the child. Finally, details show that in at least $12.7 \%$ of the cases in which the final outcome is noted in the record, the institutions failed in their programme for training, either because children ran away or because the centre found itself obliged to expel them for inappropriate behaviour. The impact of such failures was somewhat more evident among hospice children, where it reached $14.6 \%$ as against the $11.5 \%$ among foundlings. These differences, not in any case very considerable, may be linked to the greater independence of the former, who came into contact with the centres rather later. Besides, hospice children often might benefit from some family assistance that would serve as a bridge to breaking free, a type of help that foundlings lacked. It should be kept in mind, nonetheless, that this level of failures might be higher if all the required information were available for the large group of "missing".

On some occasions the registers reflect the cause leading the administrators to expel a boy. In 1804 two of them were thrown out for petty theft. Three years later, a hospice child called Isidro Palacios was expelled for the same reason. Moreover, this case is a perfect example of the level of rebelliousness with which some of these lads reacted to the authority wielded by the centre, despite its repeated attempts to re-educate them. Young Palacios was only eight when expelled and had spent nine months in the centre's care. When his mother passed away some time later, the institution re-admitted him, but he was involved thereafter in several escapes which ended up with his being put in prison, after which he went off to Zamora leaving no further trace ${ }^{44}$. On other occasions, the punishments imposed were less severe, with the administration confiscating the boys' money, so that any temptation to spend it on inappropriate vices would be removed.

Absconding was another instance of the way that some of the inmates resisted the rules set for the internal life of the Hospice ${ }^{45}$. At other times, this may be seen as a reaction to the temporary loss of the links uniting them with their family surroundings, whether birth family or paid replacements. The youngsters in the centre were subjected to an iron discipline, hard to bear at their age, especially for

43 A.H.P.L. Libros registro de entradas del Hospicio de León.

44 A.H.P.L. Libros registro de entradas del Hospicio de León.

45 In the establishment in Zamora, it would seem that the rigorous discipline and harsh punishments were the cause of quite a few absconding. Galicia Pinto, M. I., La Real Casa Hospicio de Zamora, p. 119. 
the more restless spirits. Without a scrupulous application of rigid and restrictive rules it would have been very difficult to keep the establishment under control, but on the other hand these could become excessively oppressive for many of those sheltered there. The statistics count exclusively those cases in which the escape brought the final break-away of the boy from the centre. However, on other occasions those responsible for the Hospice succeeded in getting the absconder back, calling for this purpose on the invaluable assistance of the civil authorities.

To move on to an analysis of the girls, it may be observed that the percentage of "lost" is noticeably lower than among the boys (41.1\%), with a higher figure among the hospice children (51.1\%) than among the foundling girls $(25.2 \%)$, as was also the proportion in the male group (figure 2). For this reason, the explanation suggested in that case may serve here too. In their case, there is a smaller range of vocational outlets, which corresponds to the secondary part played by women in the society of the time. Among those girls whose final destination is known, the commonest outcome was a wedding, which represented $63.1 \%$ of the total, "missing" cases excluded. The major role of marriage as the final breaking off of links between a girl and the charity is closely related to the responsibility the administrators took upon themselves to protect the honour of girls in their care. Moreover, while in the case of males a wedding was not really a "vocational outlet", for girls it can be seen as such, being the preferred destiny allotted to them by the ruling Catholic moral standard. In fact, the charities had a certain amount of money set aside to provide dowries. In 1833 the hospice assigned as dowry 320 reals to a foundling called Gertrudis, then aged 31, so she could marry a certain Manuel Baldeón in the parish of Saint Marina ${ }^{46}$. To receive the money, this woman had to produce after the ceremony a certificate from the parish priest, while her husband had to sign the appropriate receipt. This is by no means the only instance, as there are similar records right through the eighteenth century, both from the Poor Fund and from the Hospice. Marriage between inmates was also not infrequent. This is what happened in September 1838, with the wedding between Lope Blanco and María García or that celebrated in May of 1848 between the foundlings Ceferino Blanco and Regina. their origin, began to work as servants at the age of about 15 years $^{47}$. If it is kept in mind that they married at 26 on average and that hospice girls entered the institution at about 11 years old, it is obvious that the time females spent as inmates was longer than that for males, for the moral and social reasons already mentioned. As noted above, going out to work did not involve a total break

46 In 1836 another woman was given 160 reals for this purpose, in 1850 another received 280 and in 1862 a third 550. A.H.P.L. Libros registro de entradas del Hospicio de León.

47 This was slightly older than girls in the Toledo institution in the second half of the eighteenth century, for whom the average was 13.5 years. Rordríguez González, A. "La utilidad del abandono..." p. 87. 
Figure 2. Final outcome for surviving girls from the Leon centres, 1700-1830.

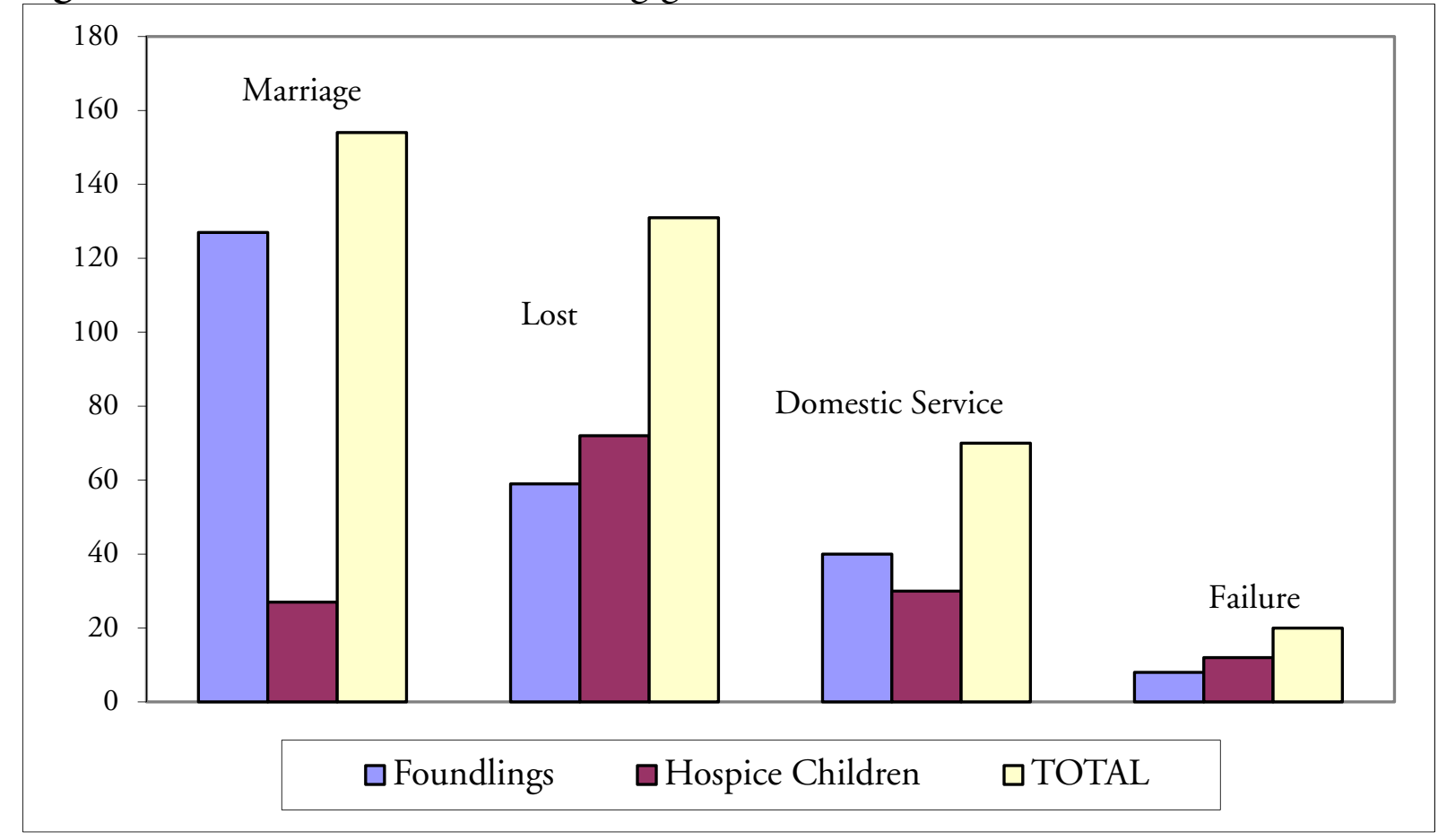

with the charity, since it continued to have a guardianship role in respect of these females ${ }^{48}$. Besides, the time spent as a servant in any one private household was usually short, with stays under twelve months in length being predominant, and returns to the institution to wait for a new assignment frequent ${ }^{49}$. During such waiting intervals, the administrators, in order to draw some benefit from this inactive workforce, could use the girls for the completion of specific tasks, whether within the centre (caring for foundlings, tending the garden, working in the kitchen, and the like) or to give temporary help to some neighbour. From time to time, also, girls with particular gifts for learning might end up by becoming part of the staff of the centre. This happened in respect of the assistant to the girls' schoolmistress in the Hospice in 1801. It also occurred in the case of a foundling girls called Valeriana, who spent a long time in domestic service, but in March 1840 , when aged 22, was taken on to teach the girls in the centre, with wages of 15 reals.

Overall, absconding and expelled girls represented a lower percentage than among the males, at $8.2 \%$. However, while for the foundlings as a group the figures are lower than for boys, for hospice girls they are slightly higher, the figures for girls expelled contributing decisively to this. Perhaps the long time-span of dependence and the iron control to which they were all subjected may have triggered a reaction

48 Costa, M., "Pauperismo y educación femenina en Barcelona", Pedralbes, 23, 2003, pp. 399-423, p. 416.

49 In Toledo it appears that increases in wages were what influenced changes of job. In Leon the files do not record this information. Rodríguez González, A. "La utilidad del abandono... p. 81 . 
of rebelliousness. Quite often, escapes by girls occurred when they took advantage of being in a private house where they were working as servants.

For their part, behind the majority of expulsions lay reasons of a moral nature, perhaps more clearly so than when boys were expelled, for obvious reasons. This was the case for the foundling who was sent to the household of Don José Blanco Chicarro as a servant in April 1822, of whom it was learnt two months later that she had run off from her job, and that while there she had led a "wicked" life, for which cause she was expelled. This does not imply there were not also instances of expulsions related to discipline, as happened to a girl who was punished in this way in October 1838 for being disrespectful, or to another, called Micaela Sánchez, who was involved in a fierce altercation with the schoolmistress ${ }^{50}$.

In any case, the greater part of the females, like the males, ended by becoming fully integrated into society, while some of them even came to enjoy a relatively comfortable financial position. Among this group was Manuela Melchora García, a foundling who, despite remaining unmarried, had come to run a modest business selling clothing and footwear. In 1833, when she died, she bequeathed the stock of her shop to a good number of people of very varied social classes and named the Hospice residual legatee of the remainder of her property. This action bears witness to her gratitude to the centre that had brought her up and given her a helping hand at the most difficult points in her life ${ }^{51}$.

\section{Internal Training: Workshops, General Education and Religion}

Information about the vocational and general educational instruction given to the children in the care of the Poor Fund is very limited. All that is available are a few unconnected details that very sketchily outline what was done. It is known that those children who came back from being raised and weaned outside were given within the centre a rudimentary general and religious education while waiting there to start working in a job. In this way, the authorities running the Poor Fund, following the trends of the period, attempted to keep this marginalized group away from another form of social exclusion: intellectual poverty ${ }^{52}$. The data also appear to show training differentiated by sex: while girls were educated within the institution by an internal schoolmistress, boys were sent out to the classes given in the City's public school, the connection with the Doctrinal School being evident

50 A.H.P.L., Libros registro de entradas del Hospicio de León.

51 A.H.P.L., Sanidad y Beneficencia, Box 339.

52 Moratinos Iglesias, J., Historia de la Educación en Alicante desde el siglo XVIII hasta comienzos del siglo XIX, Alicante 1986, p. 23. 
once again $^{53}$. This separation was a reflection of the typical characteristics of the educational system of the day, which gave each sex a very specific role. Both males and females were given suitable religious instruction until they reached 14, this being an aspect considered fundamental at the period. As well as this, they learnt to read and write, while the girls were also instructed in how to do housework, so that they could help meet the needs of the centre ${ }^{54}$ while preparing themselves for domestic service. For this reason, it is highly likely that the intensity of teaching of reading and writing was greater for boys than for girls ${ }^{55}$.

A further objective adopted by the charity, besides offering basic instruction in reading and writing, was to give inmates the chance of getting recognized vocational training. In the case of boys, the fundamental aim was for them to acquire the skills to exercise some form of trade or $\mathrm{craft}^{56}$. With this in mind, as has already been pointed out, until the 1770s they were handed over to master craftsmen in the City. From then onwards, the new financial situation enjoyed by the Poor Fund allowed it to act more directly in this task. For this purpose, it set up a small textile manufactory, which as time went by grew in size. This was a solution very much like what was done at this period by other centres of the same characteristics $^{57}$. The founding of this workshop did not, in any case, imply a definitive end to all training outside the institution, since its size did not permit it to absorb all of the inmates ${ }^{58}$.

The two areas of education in which the Poor Fund involved itself were the same as the City's Hospice developed from the moment it was founded. The

53 The pattern of training for girls was very similar to what was done in Madrid. The main difference between the two cases is that, while in Leon training took place inside the centre, in the capital city girls were sent to the school of Our Lady of Peace as soon as they reached the age for apprenticeship. Vidal Galache, B. and Vidal Galache, F., "El colegio de Nuestra Señora de la Paz para niñas 'expuestas' de Madrid a mediados del siglo XVIII", Anales del Instituto de Estudios Madrileños, 30 (1991), pp. 191-208.

54 Sherwood, Joan, "El niño expósito, cifras de mortalidad en una inclusa del siglo XVIII", Anales del Instituto de Estudios Madrileños, 1981, 18, pp. 299-312.

55 See Viñao Frago, A., "Alfabetización, lectura y escritura en el Antiguo Régimen”, en Escolano, A., Leer y escribir en España. Doscientos años de alfabetización (Madrid 1992), pp. 45-68, p. 51.

56 This is what happened in the Lisbon Children's Home as well, although in the Portuguese institution, created in 1780, the youngsters were offered a chance of going on to higher levels of study, whether at university or as military cadets. Fonte, T. A. da, No limiar da honra e da pobreza. A infância desvalida e abandonada no Alto Minho (1698-1924) (Vila Praia da Âncora 2005), p. 540.

57 Vid. Carreras Panchón, A., El problema del niño expósito..., p. 67; Cava López, Ma.G., Infancia y sociedad en la Alta Extremadura durante el Antiguo Régimen, Cáceres 2000, p. 157; Galicia Pinto, M. I., La Real Casa Hospicio de Zamora..., pp. 114-115.

58 The Zamora hospice also combined internal training with external and this was done by the Leon Hospice itself at a later stage. Galicia Pinto, M. I., La Real Casa Hospicio de Zamor, p. 114. 
Enlightenment Bishop of Leon, Don Cayetano Cuadrillero, wished to apply in the centre he set up the utilitarian mentality that was so fashionable in reformist circles. The prelate paid at his own expense for the machinery and the master craftsmen needed for the creation of workshops intended to manufacture woollen cloth. Later on, taking advantage of the closure of the Royal Manufactory of Saint Ildefonso, six master craftsman who had belonged to that establishment were taken on by the centre, which lead the Bishop and the authorities of the charity to expand production into cotton cloth as well. This attempt was a resounding failure, on the one hand because of the high cost of raw materials, and on the other because of competition from foreign products, cheaper and considerably more stylish. In consequence, the cotton workshops finally closed, only the woollen manufactory remaining open. Moreover, even this was not always financially viable, although profits were not the sole aim of those responsible, since the training activity carried out in the workshops was as important as making money.

Not all the inmates were involved in these textile workshops, since others worked on maintaining the buildings and installations, while girls were given the domestic tasks of the centre to do ${ }^{59}$. Additionally, although the manufacture of cloth was the most important activity carried out in the establishment, at certain times there were also workshops for tailoring, carpentry and shoe-making. These were intended to give the centre some degree of self-sufficiency, as well as to encourage a work ethic and to diversify the sorts of training on offer.

\section{Final Conclusions}

This study of the three charitable institutions in the Leon of the Modern Period (the Poor Fund, the Doctrinal School and the Hospice) has provided an insight into the inner workings of a question that was latent in the society of the day: the matter of assistance for poor or abandoned children. The three centres, managed by different institutions and with life-spans that also differed, undertook the work of protecting children in very similar ways in so far as their aims relating to educational and vocational training were concerned. All three stressed the importance of religious education, the teaching of basic reading and writing, and, above all, training for a trade, seen as the principal way to ensure a decent future for those in their care, although they did so with a marked differentiation by sex.

The concept of training as an objective for assistance is already glimpsed at in the sixteenth century when the Doctrinal School was established. Nevertheless, it was not until the eighteenth century that this objective acquired any significant dimensions, expressed in the form of the Poor Fund and the Hospice. This

59 A.H.P.L., Sanidad y Beneficencia, Box 339. 
development was based on the financial solvency of the two centres and the appearance of the utilitarian views championed by the Bourbon dynasty.

Alfredo Martin is Associate Professor of Modern History at the Department of History, Léon University (Spain).

\section{Acknowledgement}

This paper forms part of a project entitled Cultura letrada y cultura oral en la provincia de León a finales del Antiguo Régimen [Learnèd and Oral Culture in the Province of Leon at the End of the Modern Period], financed by the Consejería de Educación de la Junta de Castilla y León [Education Bureau of the Regional Government of Castile and Leon] (Reference LE003B08). 


\section{References}

Alfaro Pérez, F. J. and Salas Ausens, J. A., "Inserción social de los expósitos del Hospital de Gracia de Zaragoza en el silgo XVIII", Obradoiro de Historia Moderna, 10 (2001), pp. 11-27.

Aríes, Philippe, El niño y la vida familiar en el Antiguo Régimen, Madrid, 1987.

Bartolomé Martínez, B., "La crianza y educación de los expósitos en España entre la Ilustración y el Romanticismo (1790-1835)", Historia de la Educación, 10 (1991), pp. 33-62.

Caro López, C., La línea en la sombra. Estudios sobre la asistencia y la represión de los marginados en Murcia durante el siglo XVIII (Cartagena 1992).

Cava López, Gema (2000), Infancia y sociedad en la Alta Extremadura durante el Antiguo Régimen (Cáceres, 2000).

Cava López, Ma.G., Infancia y sociedad en la Alta Extremadura durante el Antiguo Régimen (Cáceres 2000).

Cavillac, M., "Introducción" in Pérez Herrera, Cristóbal, Amparo de pobres (Madrid: Espasa-Calpe, 1975), pp. LXXXV-LXXI.

Costa, M., "Pauperismo y educación femenina en Barcelona", Pedralbes, 23 (2003), pp. 399-423.

Fauve-ChamouxA., "Changing Politics towards Abandoned Children at the end of the Ancien Régime and the Responsibility of a French Hospital Administration on Infant Mortality", in World History Congress (Session: The Role of Purposive Behavior in Mortality Reduction) (Oslo 2000), (www.hnet.org/-demog/mortpap/fauve changl.doc), p. 10.

Fernández Martin, L., Asistencia social en Valladolid. Siglos XVI-XVIII (Valladolid 1999).

Fonte (da) T. A., No limiar da honra e da pobreza. A infancia desvalida e abandonada no Alto Minho (1698-1924) (Vila Praia de Âncora, 2005).

Garcá Guerra, D., El Hospital Real de Santiago (1499-1804) (Corunna 1983).

Giginta, Manuel de, Tratado de remedio de pobres (Barcelona, 2000).

González Gallego, I., "El proyecto didáctico de una institución educativa entre los siglos XVI y XIX: el Colegio de niños de la doctrina cristiana de Palencia (1544-1861)", pp. 475-497, in Actas del I Congreso de Historia de Palencia, Vol. III (Edad Moderna y Edad Comtemporánea) )Palencia 1987).

Larquie, C., "La crianza de los niños madrileños abandonados en el siglo XVIII", Anales del Instituto de Estudios Madrileños (1986), pp. 363-384.

Lope Toledo, J.M., "Logroño en el siglo XVI. Los niños de la doctrina cristiana" in Berceo, 73 (1964), pp. 419-432,.

Madoz, P., Diccionario geográfico-estadístico-histórico de España y sus posesiones de Ultramar (Valladolid 1983). 
Maravall, José Antonio, "De la misericordia a la justicia social en la economía del trabajo: la obra de Fray Juan de Robles", in Moneda y Crédito. Revista de Economía, 148 (1979), pp. 57-88.

Mora del Pozo, G., El colegio de doctrinos y la enseñanza de primeras letras en Toledo. Siglos XVI a XIX (Toledo 1984).

Moratinos Iglesias, J., Historia de la Educación en Alicante desde el siglo XVIII hasta comienzos del siglo XIX (Alicante 1986).

Rodríguez González, A., "La utilidad del abandono: la expósitas del hospital de Santa Cruz y el servicio doméstico en Toledo en la segunda mitad del siglo XVIII", in Irigoyen López, A. and Pérez Ortiz, eds., Familia, transmisión y perpetuación (siglos XVI-XIX) (Murcia 2002), pp. 75-89.

Santolaria Sierra, F., "Los colegios de doctrinos o de niños de la doctrina cristiana. Nuevos datos y fuentes documentales para su estudio", in Hispania, Vol. LVI1, 192 (1996), pp. 267-290.

Sarrailh, J., La España Ilustrada de la segunda mitad del siglo XVIII, Madrid 1974.

Torrubia Balagué, E., Marginación y pobreza. Expósitos en Salamanca (1794-1825) (Salamanca 2004).

Vidal Galache, B. and Vidal Galache, F., "El colegio de Nuestra Señora de la Paz para niñas 'expuestas' de Madrid a mediados del siglo XVIII", Anales del Instituto de Estudios Madrileños, 30 (1991).

Vidal Galache, F. and Vidal Galache, B., Bordes y bastardos. Una historia de la inclusa de Madrid (Madrid 1995).

Villacorta Rodríguez, T., El Cabildo de la Catedral de León. Estudio Históricojurídico, siglos XII-XIX (Leon 1974).

Viñao Frago, A., "Alfabetización, lectura y escritura en el Antiguo Régimen", en Escolano, A., Leer y escribir en España. Doscientos años de alfabetización Madrid (1992), pp. 45-68.

Voves, Juan Luis, Tratado del socorro de pobres [Treatise on Aiding the Poor], (Unpublished sixteenth-century translation by Bernardo Pérez de Chinchón) (Alicante, 2006). 